\title{
Effect of Social Media on College Students Academic Performance
}

\author{
Tagreed Alsulimani ${ }^{1 *}$ Rohan Sharma ${ }^{2}$ \\ 1. College of Business University of Jeddah, Saudi Arabia. \\ 2. College of Business IHGI-IKG Punjab Technical University Jalandhar, India
}

\begin{abstract}
Social media act as an online communications channels dedicated to community-based input, interaction, contentsharing and teamwork. Social media is becoming an essential part of life online as social websites and applications proliferate. The new and easy ways to of getting the knowledge have emerged using social networks in both formal and informal method. Now days demand of social media increasing everyday people love to share their ideas, views, information. The purpose of this research paper is to understand the effect of social media on academic performance of college students. Taken this into consideration 166 students were randomly taken from different colleges who were using social media as means of education tools. The study was conducted an 8-item questionnaire with Likert Scale (Disagree-1 and 5 for Agree). Various aspects of behavior \& Social Networking pattern were taken into consideration. The analysis was done based on Mean \& t-test, the result shows that Social Media put positive impact on behavior of the students but has not changed the academic performance of the students in terms of improved grades. It was also found that Female students are using more social media than the male students.
\end{abstract}

Keywords Social media, communications channels, performance

DOI: $10.7176 / \mathrm{EJBM} / 11-9-20$

Publication date:March $31^{\text {st }} 2019$

\section{Introduction}

Social media act as an online communications channels dedicated to community-based input, interaction, contentsharing and teamwork. Social media is becoming an essential part of life online as social websites and applications proliferate. In today time social media is the one of the most important components which helps in connecting the people, the evolution of the internet made the life of people easy and simple. It has been seen that whereby two-third $(2 / 3)$ of the internet world 's population visit social networking sites (SNSs) thus serving as communication and connection tools. (Boyd and Ellison, 2007). This has breached the gab that existed in communication where people had to rely solely on traditional methods such as letters and phone calls as a mode of getting in touch with friends and relatives.

Today, communication is as easy as walking into a neighbor's residence to deliver a piece of information or vice versa using social media. Social media is fast changing the public discourse in the society and is setting trends and agenda in topics that ranges from the environment and politics to technology and the entertainment industry. The driving factors for adoption of social media are the progressively ubiquitous access, convenience, functionality, and flexibility of social technologies. These factors have made the adoption of social media very easy.

The new and easy ways to of getting the knowledge have emerged using social networks in both formal and informal method. Now days demand of social media increasing everyday people love to share their ideas, views, information. With this sharing of academic information play an important role through social media. As the demand of smart phone increasing day by day the use of social media also increased. People feel happy and satisfied while sharing their information on social media. (Note 1).

\subsection{Review of Literature}

Georgios Zachos (2018): The paper focus on the role of social media on students' academic performance, as it social media helps to share information. Now days students feel happy and satisfied while share information to the audience or to their friends as social media helps to get new information to the students regarding their studies. Through the social media students get latest and quick information and share the information with their friends. (Note 2)

Caren Casama \& Randy Joy (2017): The modern world digital age has opened great opportunities for people universally to join with each other and right get a diverse range of information. The Internet provides huge amount of information resources which are very useful for a variety of purposes in education, work and business as well 
as in keeping up with world trends. This study was conducted to understand the impact of social media in education based on the perceptions and practices of teachers. The results show that social media put huge impact on education.

Mensah \&Nizam (2016): The paper focused on the social media and its usage in in the health sector. The different factor has been taken into consideration in which role of social media has been used for health sector. among the six variables used in their study, the results show that social media play an important in the health issues. Concluded in their study that social media platforms have a significant impact on students' academic performance in Malaysia tertiary institutions.

Owusu-Acheaw \& Larson (2015): it was seen that the use of social media had put positive impact on the academic performance of their respondents and further confirmed that there was a strong positive relationship between the use of social media and academic performance. The study further revealed that respondents use social media sites to group chat rather than for academic purpose

Alwagait, Shazad and Alim (2014): The papers focus on the different aspect of social media that social media mostly in the morning and the evening time period. It has also seen that most of the young people use social media

Kolan and Dzadza (2018): the finding of the study focusses on most of the social media networks such as sharing of information, building relationship, partaking in group discussion, there is to some extent addiction and distraction of attention caused using social media which could have serious consequences on the academic life of students. One of the negative effects of social media is piracy. The primary motivator for Australians of all ages illegally downloading movies and TV shows is that it is free

Landry (2014): social media a tool that could be used for good or bad, it all depends on the person. Social media has its layers of good and bad. Yes, it is easier to remember the bad rather than the good but, social media sites have created opportunities for people all over the world

\section{Objective}

1. To ascertain how the use of social media has influenced the academic work of students.

2. To understand the use of social media by the students on the bases of gender.

\subsubsection{Methodology}

Sample:

The present research was conducted on a sample consisting of 166 students that were randomly drawn from different Colleges. The age of Students varies from 18-23 years

Tool Used:

The questionnaire by BJ Kolan \& PE Dzandza (2018) scale was used to measure Students behavior towards social media. There are 8 items in the scale and measures the Students behavior. Reliability and validity of coefficients were within the acceptable norms.

\section{Procedure}

The questionnaires were distributed to the college students and they were asked to read the instructions given in the questionnaires. No time limit was given to fill the questionnaire, but it was expected that respondents would fill the same within 5-10 minutes. 


\subsubsection{RESULTS AND DISCUSSION}

Table 1. Showing the Mean value \& Standard Deviation of college students

\begin{tabular}{|c|c|c|c|c|}
\hline $\mathrm{Sr} \mathrm{No}$ & Variables & $\mathrm{N}$ & Mean & $\begin{array}{c}\text { Std. } \\
\text { Deviation }\end{array}$ \\
\hline 1 & $\begin{array}{l}\text { The usage of materials from Wikipedia for research has helped improve my } \\
\text { grades. }\end{array}$ & 166 & 4.0606 & .95883 \\
\hline 2 & $\begin{array}{l}\text { I use materials obtained from social networking sites to complement what I have } \\
\text { been taught in class. }\end{array}$ & 166 & 3.9848 & .85020 \\
\hline 3 & $\begin{array}{l}\text { Engaging in academic forums on social media increases my understanding of } \\
\text { topics discussed in class. }\end{array}$ & 166 & 4.2273 & .81892 \\
\hline 4 & $\begin{array}{l}\text { Group discussions on social media yield good results as far as my academics } \\
\text { are concerned. }\end{array}$ & 166 & 3.8182 & 1.17551 \\
\hline 5 & $\begin{array}{l}\text { I am addicted to social networks and this is a challenge that affects my academic } \\
\text { life. }\end{array}$ & 166 & 3.5606 & 1.00963 \\
\hline 6 & Online social networks distract me from my studies. & 166 & 3.4394 & 1.37145 \\
\hline 7 & Time spent on social media can never be compared to time spent on my studies. & 166 & 3.8788 & .75478 \\
\hline 8 & $\begin{array}{l}\text { There is no improvement in my grades since I became engaged into these social } \\
\text { networking sites. }\end{array}$ & 166 & 2.2121 & 1.15712 \\
\hline
\end{tabular}

Description for the above table. The Table 1 shows that the social media play an important role in the academics. The results prove that social media helps in the academics of a students. The mean values of all the variables were quite high except on few. It is evident from the Table that Engaging in academic forums on social media increases my understanding of topics discussed in class is having highest mean value followed by The usage of materials from Wikipedia for research has helped improve my grades and I use materials obtained from social networking sites to complement what I have been taught in class respectively. But it is surprising to note that on the last dimension of the scale There is no improvement in my grades since I became engaged into these social networking sites is very surprising and needs further investigation that why these social media instruments were not helpful in getting the Grades improved. The overall results of table1 shows students were happy and satisfied with social networking site enjoy social media as a form of communication and also apparently showing that social networking sites helping them in their academics but in fact it is not true because the end result that is Grade in the exams were not increased. 
Table: 2 shows the result based on gender.

\begin{tabular}{|c|c|c|c|c|c|}
\hline Sr No & Gender & $\mathrm{N}$ & Mean & $\begin{array}{c}\text { Std. } \\
\text { Deviation }\end{array}$ & $\mathrm{t}$ value \\
\hline \multirow{2}{*}{1} & Female & 93 & 4.1860 & 1.13925 & \multirow[b]{2}{*}{1.879} \\
\hline & Male & 73 & 3.8261 & .38755 & \\
\hline \multirow{2}{*}{2} & Female & 93 & 4.0698 & 1.00937 & \multirow[b]{2}{*}{1.402} \\
\hline & Male & 73 & 3.8261 & .38755 & \\
\hline \multirow{2}{*}{3} & Female & 93 & 4.4419 & .90770 & \multirow[b]{2}{*}{$3.842 *$} \\
\hline & Male & 73 & 3.8261 & .38755 & \\
\hline \multirow{2}{*}{4} & Female & 93 & 3.6279 & 1.17561 & \multirow[b]{2}{*}{1.861} \\
\hline & Male & 73 & 4.1739 & 1.11405 & \\
\hline \multirow{2}{*}{5} & Female & \multirow{2}{*}{$\begin{array}{l}93 \\
73 \\
\end{array}$} & \multirow{2}{*}{$\begin{array}{l}3.8140 \\
3.0870 \\
\end{array}$} & .39375 & \multirow[t]{2}{*}{$2.948 *$} \\
\hline & Male & & & 1.53484 & \\
\hline \multirow{2}{*}{6} & Female & \multirow{2}{*}{$\begin{array}{l}93 \\
73 \\
\end{array}$} & \multirow{2}{*}{$\begin{array}{l}3.6279 \\
3.0870 \\
\end{array}$} & 1.09160 & \multirow[t]{2}{*}{1.543} \\
\hline & Male & & & 1.75585 & \\
\hline \multirow{2}{*}{7} & Female & \multirow{2}{*}{$\begin{array}{l}93 \\
73 \\
\end{array}$} & \multirow{2}{*}{$\begin{array}{r}3.9767 \\
3.6957 \\
\end{array}$} & .73964 & \multirow[t]{2}{*}{1.454} \\
\hline & Male & & & .76484 & \\
\hline \multirow{2}{*}{8} & Female & 93 & 2.3953 & 1.38254 & \multirow[b]{2}{*}{$2.361 *$} \\
\hline & Male & 73 & 1.8696 & .34435 & \\
\hline
\end{tabular}

\section{*: Significant at .05 level of significant}

Description for the above table. The Table 2 shows the result on the basis of gender, the values of the variables are in the favor of social media role that Social media play an important role in academic performance of the students, the results shows that female students having overall high mean value as compare to male students on the dimensions of 3,5 and 8. On the dimension of Engaging in academic forums on social media increases my understanding of topics discussed in class female students were found have higher mean value than the male students and the difference were found to be significant at .05 level of significance. While on the dimension of I am addicted to social networks and this is a challenge that affects my academic life again the female students were showing high mean value than the male students mean they are more addict of social media than male members. At the last it was on the dimension of There is no improvement in my grades since I became engaged into these social networking sites females were showing low mean value than male counterparts are the indication that despite using more and more social media for their academic improvement the grades have not changed or improved. Here it is matter of concern that despite using social media as one of the sources for academic improvement or better understanding the grades were not improved. This is matter of another research to find out the reason or may the means and ways of using the social media.

\section{Conclusion}

The results show that in today's scenario the social media play an important role, the role of social media in academics become more important. As results shows that now days social media helps to improve students in their academic's performance, as per the student's information available on the social media or on the internet are much more advance as compare to the books and it is easy to access. The social media helps to share information and feel happy and satisfied while share information to the audience or to their friends as social media helps to get new 
information to the students regarding their studies. Through the social media students get latest and quick information and share the information with their friends. The Internet provides huge amount of information resources which are very useful for a variety of purposes in education, work and business as well as in keeping up with world trends. The results show that social media makes a huge impact on education of the students but here in this case failed to improve the existing grades of the students. It means though the social media is an available tool of knowledge enhancement and better understanding, but the students has to make some other extra efforts to improve their grades.

\section{References}

Alwagait, E., Shahzad, B. (2014). Impact of social media usage on students' academic performance in Saudi Arabia, Computers in Human Behavior, http://dx.doi.org/10/1016/j.chb.2014.09.028

Arquero, J. L., \& Esteban, R., (2013). Using social network sites in Higher education: an experience in business studies. Journal of innovations in education and teaching international.DOI:10.1080/14703297.2012.760772.

Asur, S. \& Huberman, B.A. (2010). Predicting the Future with social media. WI-IAT'10 Proceedings of the 2010 IEEE/WIC/ACM International Conference on Web Intelligence and Intelligent Agent Technology, 1. DOI:10.1109/WI-IAT.2010.63. Retrieved from http://www.researchgate.net/publication/45909086.

Boyd, D. M \& Ellison, N. B. (2007). Social network sites: definition, history and scholarships. Journal of computer-mediated communication, 13(1) (2007) pp.210-230. DOI:10.1111/j.1083- 6101.2007.00393.x.

Brown, S. (2010). From VLEs to Learning webs: the implication of Web 2.0 for learning and teaching. Interactive Learning Environments, 18(1) pp. 1-10. Retrieved from http://dx.doi.org/10.1080/10494820802102158983.

Calvete, E., Orue, I., Estevez, A., Villardon, L., \& Padilla, P. (2010). Cyberbullying in adolescents: Modalities and aggressors' profile. Computers in Human Behavior, 26. DOI: 10.1016/j.chb.2010.03.017.

Colley, H.; Hodkinson, P.; Malcolm, J. Non-Formal Learning: Mapping the Conceptual Terrain, a Consultation Report. Available online: http://eprints.hud.ac.uk/id/eprint/13176/ (accessed on 30 October 2018).

Davies, T., \& Cranston, P. (2008). Youth work and social Networking. Final research report. How youth can work best to support young people to navigate the risks and make the most of the opportunities of online social networking? National youth agency and research. Retrieved from http://www.nya.org.uk/resource/youth-worksocial-networking.

Jarvis, P. Adult Learning in the Social Context; Croom Helm: London, UK, 1987.

Jeff’s, T.; Smith, M. Using Informal Education; Open University Press: Buckingham, UK, 1990.

Kolan, B., Dzandza, P. (2018). Effect of social media on academic performance of students in Ghanaian Universities: A case study of University of Ghana, Legon, Library Philosophy and Practice (e-journal), https://digitalcommons.unl.edu/libphilprac/1637.

Landry, T. (2014). How Social Media Has Changed Us: The Good and The Bad. Retrieved from https://returnonnow.com/2014/09/how-social-media-has-changed-us-the-good-and-the-bad/.

M. Owusu-Acheaw\& Agatha Gifty Larson (2015): "Use of Social Media and its Impact on Academic Performance of Tertiary Institution Students: A Study of Students of Koforidua Polytechnic, Ghana”, Journal of Education and PracticeVol.6, No.6, ISSN 2222-1735.

Sandra Okyeadie Mensah \& Dr. Ismail Nizam (2016): “THE IMPACT OF SOCIAL MEDIA ON STUDENTS' ACADEMIC PERFORMANCE- A CASE OF MALAYSIA TERTIARY INSTITUTION”, International Journal of Education, Learning and Training. Vol. 1 (1) ISSN: 2289-6694. 